The Comparative

Perspective on Literature 


\section{The Comparative}

\section{Perspective on Literature}

\section{APPROACHES TO THEORY AND PRACTICE}

EDITED AND WITH AN INTRODUCTION BY

Clayton Koelb AND Susan Noakes

CORNELL UNIVERSITY PRESS 
Copyright (C) 1988 by Cornell University

All rights reserved. Except for brief quotations in a review, this book, or parts thereof, must not be reproduced in any form without permission in writing from the publisher. For information, address Cornell University Press, 124 Roberts Place, Ithaca, New York $14^{8} 5^{\circ}$.

First published 1988 by Cornell University Press.

International Standard Book Number (cloth) o-8o 1 4-203 1-8 International Standard Book Number (paper) o-8o 14-9477-X Library of Congress Catalog Card Number 87-25062

Printed in the United States of America Librarians: Library of Congress cataloging information appears on the last page of the book.

The paper in this book is acid-free and meets the guidelines for permanence and durability of the Committee on Production Guidelines for Book Longevity of the Council on Library Resources. 